DOI https://doi.org/10.30525/978-9934-26-183-1-20

\title{
ЗАСТОСУВАННЯ ІНТЕРАКТИВНИХ ТЕХНОЛОГІЙ НАВЧАННЯ НА ЗАНЯТТЯХ 3 ХІМІЇ
}

\author{
Чигвінцева О. П. \\ кандидат технічних наук, доцент, \\ завідувачка кафедри хімії \\ Дніпровський державний аграрно-економічний університет \\ Бойко Ю. В. \\ старший викладач кафедри хімії \\ Дніпровський державний аграрно-економічний університет \\ м. Дніпро, Украӥна
}

Зміни, що відбуваються у сучасному світі, впливають на завдання і цілі сучасної вищої освіти. Відбувається поступове зниження актуальності і привабливості традиційних методів навчання і зростає необхідність впровадження в учбовий процес інтерактивних методів навчання. Використання інтерактивних технологій дозволяє суттєво покращити якість освіти, створити необхідні умови для формування таких якостей сучасної молоді, як мобільність, уміння інтегруватись у динамічне суспільство та генерувати нові ідеї, критичність мислення, здатність приймати нестандартні рішення та нести за них відповідальність, комунікативні уміння, уміння працювати в команді, уміння моделювати навчальні та виховні ситуації тощо [1, с. 140].

Саме інтерактивні технології, під якими розуміють здатність до діалогу і взаємодії між викладачем та учасниками освітнього процесу, дозволяють створити комфортні умови навчання, за яких кожен здобувач вищої освіти відчуває свою успішність та інтелектуальну спроможність. Таке навчання у співпраці дозволяє усім учасникам процесу бути рівноправними і рівнозначними суб'єктами навчання [2, c. 7].

Сучасні вимоги до випускників закладів вищої освіти передбачають наявність певного комплексу знань та навичок, вміння швидко аналізувати ситуацію та знаходити оптимальне рішення, наявність ключових компетенцій, необхідних для майбутнього фахівця. Тому у здобувачів вищої освіти необхідно формувати та постійно підтримувати бажання до самоосвіти, особливо з дисципліни «Хімія», яка $\epsilon$ фундаментальною базою для вивчення багатьох дисциплін спеціалізованого 
напрямку. На нашу думку це можливо здійснити за рахунок впровадження інтерактивних технологій та методик навчання, на основі яких формуються основні цілі вивчення хімії [3, с. 188]. Наприклад, 3 використанням технології колективно-групового навчання і проблемнопошу-кової технології доцільно провести лабораторне заняття з хімії на тему «Хімія сполук $d$-елементів».

Метали, що належать до $d$-електронної родини, мають важливу біологічну роль, що обумовлено їх здатністю брати участь у реакціях комплексоутворення, гетерогенних та протолітичних реакціях у живому організмі. Знання будови атомів, властивостей та біологічної ролі $d$-елементів та їх сполук необхідні здобувачам вищої освіти для засвоєння деяких розділів біохімії, агрохімії, фармакології, фізіології та спеціальних дисциплін. Розуміння ролі їх сполук та метаболічних реакцій неможливе без попереднього вивчення властивостей елементів та їх простих сполук.

Розробка лабораторного заняття 3 використанням інтерактивних методів навчання має наступні основні цілі: трактування взаємозв'язку між біологічною роллю біогенних $d$-елементів та формою знаходження їх в організмі; аналіз взаємозв'язку між хімічними властивостями сполук $d$-елементів та їх вмістом в організмі; вміння складати електронні формули атомів та іонів $d$-елементів в основному та збудженому станах; складати молекулярні та структурні формули речовин; визначати ступені окиснення атомів $d$-елементів елементів та проводити хімічні реакції якісного визначення мікроелементів у розчинах.

В ході проведення заняття розглядаються теоретичні питання: поняття про «метали життя»; електронна структура та електронегативність біогенних $d$-елементів; типові хімічні властивості $d$-елементів та їх сполук (реакції, що здійснюються зі зміною ступеня окиснення та реакції комплексоутворення); біологічна роль біогенних $d$-елементів; токсична дія $d$-елементів та їх сполук; цікаві факти про $d$-елементи.

Викладач пропонує студентам здійснити подорож за форматом «Світ навиворіт»: спочатку розглядаються властивості елемента, його характерні риси, а потім необхідно відгадати, що це на $d$-елемент та знайти його на мапі (студенти розподіляються на дві команди, які будуть змагатися; переможе та команда, яка обрала максимальну кількість балів). Розглядається електронна конфігурація $d$-елементів, їх валентні електрони, поняття про є «провал електрона».

Типовими хімічними властивостями сполук $d$-елементів $\epsilon$ реакції зі зміною ступеня окиснення та комплексоутворення: 


$$
\begin{gathered}
4 \mathrm{Fe}(\mathrm{OH})_{2}+\mathrm{O}_{2}+2 \mathrm{H}_{2} \mathrm{O} \rightarrow 4 \mathrm{Fe}(\mathrm{OH})_{3} \downarrow \\
\mathrm{CoCl}_{2}+4 \mathrm{NH}_{4} \mathrm{SCN} \rightarrow\left(\mathrm{NH}_{4}\right)_{2}\left[\mathrm{Co}(\mathrm{SCN})_{4}\right]+2 \mathrm{NH}_{4} \mathrm{Cl}
\end{gathered}
$$

Здатність $d$-елементів утворювати хімічний зв'язок $d$-електронами і $d$-орбіталями зумовлює (версії студентів, за якими нараховуються бали за правильні відповіді): забарвленість їх сполук; різноманітність ступенів окиснення; високу здатність до комплексоутворення, що пояснює їх біологічну роль.

Окисно-відновні властивості пов'язані зі здатністю елементів та їх сполук віддавати або приєднувати електрони, тобто змінювати ступінь окиснення. У вільному стані метали $є$ донорами електронів, тобто віддають свої валентні електрони іншому атому і тому є відновниками.

Перехідні елементи мають незавершену $d$-орбіталь, тому ступінь окиснення їх у сполуках є змінною. 3 цим пов'язана багатоманітність окисно- відновних реакцій $d$-елементів (студенти наводять приклади, отримують додаткові бали): $+24 \mathrm{Cr} \quad 1 s 22 s 22 p 63 s 23 p 63 d 54 s 1$; +25 Mn 1s22s22p63s23p63d54s2;

Зі збільшенням порядкового номеру вздовж періоду спостерігається, в цілому, збільшення здатності до комплексоутворення, що пояснюється зменшенням радіусів і збільшенням їх поляризуючої дії. У підгрупах $d$-елементів зі збільшенням порядкового номера величина координаційного числа збільшується.

3 використанням проблемно-пошукових методів навчання викладач створює проблемну ситуацію, наприклад, ставить питання щодо розгляду проблеми біологічної ролі та токсичних властивостей $d$-елементів, організує колективне обговорення знайденої інформації, стимулює висування своїх гіпотез, тощо. При цьому викладач обов'язково приймає участь у цьому обговоренні за допомогою запитань-підказок.

Розглядаючи біологічну роль біогенних $d$-елементів заслуховуються версії студентів: вони входять до складу гемоглобіну; беруть участь в процесах обміну речовин, тканинного дихання та кровотворення; входять до складу ферментів пероксидази, каталази, альдолази; впливають на діяльність залоз внутрішньої секреції; $\epsilon$ компонентами ферментативних систем, приймають участь у білковому, ліпідному, вуглеводневому, мінеральному обміні; впливають на процеси розмноження, росту і розвитку; активують ферменти; зв'язують «неорганічний азот», який задіяний у процесах біосинтезу білків, НК, ферментів; проявляють ліотропну дію (знижують відкладання жиру); знижують рівень глюкози в крові; сприяють синтезу гормонів та ін. 
Токсичні властивості багатьох $d$-елементів обумовлені їх здатністю до комплексоутворення. Зокрема, отруєння сполуками $d$-елементів пояснюється утворенням в організмі міцних комплексів з білками, ферментами, внаслідок чого порушуються важливі процеси обміну. Наприклад: сполуки Cr (VI) належать до групи найбільш сильних канцерогенних речовин з-поміж неорганічних сполук. За даними Міжнародного агентства досліджень раку, Хром (VI) належить до I групи, тобто до групи речовин із доведеним епідеміологічним канцерогенним впливом. Найважливішою причиною мутагенної активності сполук $\mathrm{Cr}(\mathrm{VI}) \epsilon$ його окисна здатність.

Цікаві факти про хімічні елементи знаходять і повідомляють студенти. Для цього використовується технологія колективно-групового навчання „Мікрофон» [4, с. 63]. Представник кожної команди тримаючи уявний мікрофон повідомляє нову інформацію стосовно отриманого завдання. Перемагає команда, яка повідомить більше фактів про конкретний d-елемент.

Наприклад, цікаві факти про Хром:

- першовідкривачем хрому $є$ французький хімік - Л. Воклен (1797 р.);

- найбільше родовища хрому в світі знаходиться в ПівденноАфриканській республіці;

- 85\% видобутого хрому, йде для створення металевих сплавів (додавання хрому підвищує корозійну стійкість і твердість сплавів). Хром використовується при хромуванні різних виробів (автомобілі, труби та ін). Хромування сприяє зниженню тертя, підвищенню зносостійкості і корозійної стійкості (хромовані вироби не іржавіють);

- зниження кількість хрому в крові і їжі призводить до підвищення рівня холестерину у крові. Хром підтримує оптимальний тиск крові;

- хром входить до складу тканин тварин і рослин, в середньому в організмі людини міститься $0,4-6$ мг хрому;

- у чистому вигляді хром $є$ токсичним.

Далі команди проводять лабораторні досліди, які демонструють хімічні властивості $d$-елементів. Наприклад, проводять досліди щодо утворення і вивчення амфотерних властивостей хром(III) оксиду $[5$, c. 21$]$.

3 метою закріплення отриманих знань студенти виконують тестові завдання, завдання і задачі для самоконтролю, після чого підводять підсумки заняття, рахують кількість набраних балів і викладач оголошує команду-переможця. 
Наприклад, команди знаходять відповідність між стовпчиками, закінчуючи вираз:

\begin{tabular}{|l|l|}
\hline $\begin{array}{l}\text { 1. Сполуки } d \text {-елементів з мінімальним } \\
\text { ступенем окиснення виявляють ... }\end{array}$ & $\begin{array}{l}\text { а) лише окисні і кислотні } \\
\text { властивості }\end{array}$ \\
\hline $\begin{array}{l}\text { 2. Сполуки } d \text {-елементів } 3 \\
\text { максимальним ступенем окиснення } \\
\text { виявляють ... }\end{array}$ & б) окисні і амфотерні властивості \\
\hline $\begin{array}{l}\text { 3. Сполуки } d \text {-елементів з проміжним } \\
\text { ступенем окиснення виявляють ... }\end{array}$ & $\begin{array}{l}\text { в) тільки відновні і основні } \\
\text { властивості }\end{array}$ \\
\hline 4. Оксид Хрому (ІІІ) виявляє ... & г) амфотерні властивості \\
\hline & $\begin{array}{l}\text { д) тільки відновні і кислотні } \\
\text { властивості }\end{array}$ \\
\hline
\end{tabular}

Знаходять правильну електронну формулу, що характеризує валентні електрони атома Хрому:
а) $3 d^{5} 4 s^{2}$ б) $3 d^{5} 4 s^{1}$ в) $3 d^{4} 4 s^{2}$
г) $4 d^{4} 4 s^{2}$

На занятті використовується метод рефлексії «П'ять пальців», який запропонував Л. Зайверт - професор, керівник інституту стратегії використання часу (м. Гейдельберг, Німеччина). Метод полягає у тому, що потрібно лише поглянути на долоню правої руки і по перших літерах назв пальців пригадати i назвати ті принципи, на підставі яких здійснюється самоаналіз.

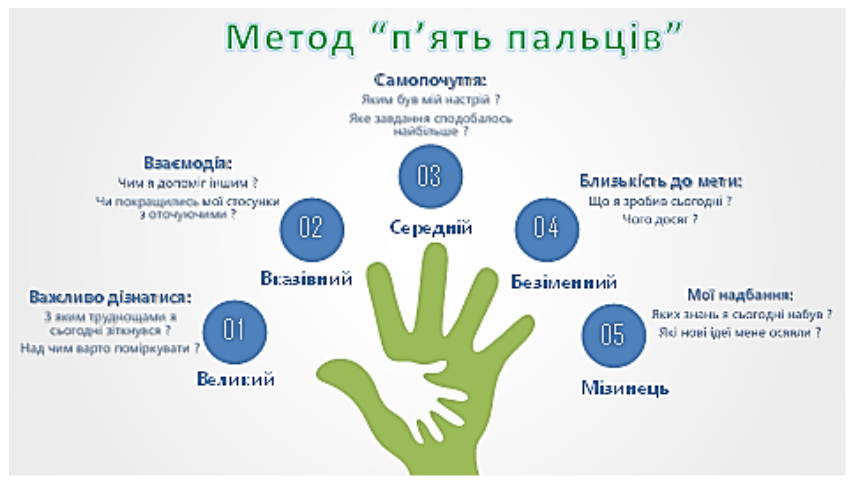

\section{Література:}

1. Остапчук Д., Мирончук Н.М. Інтерактивні методи навчання у вищих навчальних закладах. Збірник наукових праць «Модернізація 
вищої освіти в Україні та за кордоном». Житомир. Вид-во ЖДУ ім. І. Франка. 2014. С. 140-143.

2. Пометун I. О. Сучасний урок. Інтерактивні технології навчання: наук.-метод. посібник. К.: Видавництво А.С.К. 2004. 192 с.

3. Чигвінцева О.П., Бойко Ю.В. Застосування інноваційних технологій навчання хімії в умовах вищого закладу освіти. Колективна наукова монографія «Сучасний педагогог». Том 1. Дніпро: Акцент ПП, 2020. C. 186-196.

4. Пометун О. Енциклопедія інтерактивного навчання. Київ. 2007. $141 \mathrm{c}$.

5. Бойко Ю.В., Чигвінцева О.П. Методичні рекомендації до виконання лабораторної роботи «Хімія сполук $\mathrm{d}$-елементів» 3 використанням технології колективно-групового навчання, проблемно-пошукової технології та еврістичного методу. Дніпро: «Друкар». $2021.28 \mathrm{c}$. 